\title{
PERBAIKAN MUTU BUNGKIL KOPRA MELALUI BIOPROCESSING UNTUK BAHAN PAKAN IKAN BANDENG
}

\author{
Neltje Nobertine Palinggi, Usman, Kamaruddin, dan Asda Laining \\ Balai Penelitian dan Pengembangan Budidaya Air Payau \\ Jl. Makmur Dg. Sitakka No 129, Maros 90512, Sulawesi Selatan \\ E-mail: neltje_npt@yahoo.co.id
}

(Naskah diterima: 11 April 2014; Revisi final: 29 Oktober 2014; Disetujui publikasi: 10 November 2014)

\begin{abstract}
ABSTRAK
Bungkil kopra adalah hasil ikutan dari ekstraksi minyak dari daging buah kelapa kering yang masih mengandung protein sekitar 16\%-18\% dan berpotensi digunakan sebagai bahan pakan ikan. Faktor pembatas penggunaan bungkil kopra adalah kualitas nutrisi yang rendah antara lain karena kandungan lemak kasarnya agak tinggi dan mudah tengik sehingga perlu peningkatan ketersediaan biologisnya melalui fermentasi menggunakan mikroorganisme. Mikroba yang digunakan terdiri atas (A) Aspergillus niger, (B) Saccharomyces cereviceae, (C) Rhizopus sp., dan (D) Bacillus subtilis. Bungkil kopra yang sudah difermentasi kemudian dikeringkan dan ditepungkan, lalu dilakukan analisis proksimat, uji ketengikan dengan menentukan bilangan peroksidanya, dan komposisi asam aminonya. Juga dilakukan analisis kecernaannya untuk ikan bandeng ukuran sekitar $50 \mathrm{~g}$ dengan metode marker menggunakan krom oksida $\left(\mathrm{Cr}_{2} \mathrm{O}_{3}\right)$. Dari hasil penelitian ini diperoleh fermentasi dapat meningkatkan kandungan protein bungkil kopra $21 \%-42 \%$ dan menurunkan kandungan lemak dan serat kasarnya masing-masing $50 \%$ dan $27 \%$ pada fermentasi menggunakan Rhizophus sp., serta menurunkan bilangan peroksida $10 \%-47 \%$. Nilai koefisien kecernaan protein dan lemak bungkil kopra yang difermentasi dengan Rhizopus sp., A. niger, dan S. cereviceae lebih tinggi masingmasing 10\%-11\% dan 9\%-13\% dibanding bungkil kopra yang difermentasi dengan $B$. subtilis dan tanpa fermentasi. Bungkil kopra hasil fermentasi dengan Rhizopus sp. mengalami peningkatan kualitas nutrisi yang terbaik untuk bahan pakan ikan bandeng.
\end{abstract}

KATA KUNCl: bungkil kopra, fermentasi, bahan pakan, ikan bandeng

ABSTRACT: Improvement copra cake quality through bioprocessing as a dietary ingredient for milkfish. By: Neltje Nobertine Palinggi, Usman, Kamaruddin, and Asda Laining

Copra cake is a by product of oil extraction from dried coconut meat. Which contains crude protein around 16\%-18\% and potential to be used as feed ingredient. The use of copra cake meal is limited by its low nutritive quality such as high lipid content that can easily become rancid. It needs to improve the bioavailability of copra cake meal through fermentation. Microorganisms used as fermentor were (A) Aspergillus niger, (B) Saccharomyces cereviceae, (C) Rhizopus sp., and (D) Bacillus subtilis. Fermented copra cake was harvested, dried and grinded for analysis. Several analysis were carried out including proximate analysis, rancidity test by determining the peroxide number, and amino acid profiles. Digestibility trial was also conducted using milkfish about $50 \mathrm{~g}$ with marker used was chromium oxide $\left(\mathrm{Cr}_{2} \mathrm{O}_{3}\right)$. Results of this study showed that fermentation of copra cake with Rhizophus sp., increase the protein content by $21 \%-42 \%$, reduce fat and fiber content by $50 \%$ and $27 \%$, respectively, and reduce peroxide value by $10 \%-47 \%$. Digestibility coefficient of protein and fat of copra cake 
fermented with Rhizopus sp., A. niger, and S. cereviceae were higher by $10 \%-11 \%$ and $9 \%-13 \%$, respectively, compared to copra cake fermented with $\boldsymbol{B}$. subtilis and without fermentation. Fermentation of copra cake with Rhizopus sp. increased its nutritional quality for milkfish feed ingredient.

\section{KEYWORDS: copra cake, fermentation, feed ingredient, milkfish}

\section{PENDAHULUAN}

Kopra adalah buah kelapa yang dikeringkan dan digunakan sebagai sumber minyak. Bungkil kopra merupakan hasil ikutan dari ekstraksi daging buah kelapa kering (Woodrof, 1979). Bungkil kopra masih mengandung protein, karbohidrat, mineral, dan sisa-sisa minyak yang masih tertinggal (Child, 1964). Karena kandungan protein yang cukup tinggi (16\%$18 \%$ ) maka bungkil kopra masih potensial dijadikan bahan pakan ikan. Faktor pembatas penggunaan bungkil kopra adalah kualitas nutrisi yang rendah antara lain kandungan lemak kasarnya agak tinggi dan mudah tengik. Agar bungkil kopra ini dapat dimanfaatkan dengan baik oleh ikan, maka perlu diupayakan peningkatan ketersediaan biologis bahan pakan tersebut antara lain dengan penambahan mikroorganisme.

Aspergillus niger merupakan kapang penghasil amilase, glukoamilase, protease, laktase, katalase, glukosa oksidase, lipase, selulase, hemiselulase, dan pektinase (Suhartono, 1989). Selain itu, A. Niger menghasilkan beberapa enzim ekstra seluler lainnya seperti mananase dan $\alpha$-galaktosidase (Madigan \& Martinko, 2006). A. niger dapat menyintesis protein dengan mengambil sumber karbon dari karbohidrat (misalnya glukosa, sukrosa, atau maltosa), sumber nitrogen dari bahan organik atau anorganik, dan mineral dari substratnya (Fardiaz, 1989).

Saccharomyces cereviceae adalah salah satu jenis cendawan tergolong khamir yang bermanfaat untuk manusia dan ternak (Ahmad, 2005). Sejak zaman Mesir kuno S. cereviceae telah digunakan sebagai salah satu bahan utama dalam pembuatan roti dan kue. S. cereviceae menghasilkan enzim kitinase, protease, invertase, asam fosfatase, melibiase, katalase, glukanase, glukosidase, glukoamilase, fosfolipase (Lampen, 1968 dan Lodder, 1970).

Rhizopus sp. merupakan kapang yang penting dalam industri makanan sebagai penghasil berbagai macam enzim seperti $\alpha$-amilase, protease, pektinase, dan lipase (Karmini et al., 1996). Kapang dari Rhizopus sp. juga telah diketahui sejak lama sebagai kapang yang memegang peranan utama pada proses fermentasi kedele menjadi tempe.

Bacillus subtilis adalah salah satu bakteri yang bersifat termofilik fakultatif. Bakteri ini dapat menghasilkan enzim protease, $\alpha$ amilase, dan rennin (Darwis \& Sukara, 1990). Graumann (2007) mengemukakan bahwa $B$. subtilis mampu menghidrolisis ikatan kimia selulosa menjadi senyawa karbohidrat terlarut yang digunakan sebagai sumber energi untuk pertumbuhannya. Semakin banyak selulosa yang didegradasikan maka semakin menurun serat kasar dalam bahan pakan.

Fermentasi bungkil kopra dengan menggunakan mikroorganisme dapat meningkatkan kadar protein bungkil kopra 4,57\%-28,14\% (Palinggi, 2008b). Fermentasi menggunakan Aspergillus niger dapat meningkatkan kandungan protein dedak halus dan tepung darah masing-masing sebesar $18,38 \%$ dan $15,81 \%$ (Palinggi, 2003 dan Palinggi, 2008a). Penggunaan $7 \%$ bungkil kedelai dan $8 \%$ bungkil kopra yang sudah difermentasi dengan $A$. niger dalam pakan ikan kerapu macan dapat meningkatkan laju pertumbuhan harian ikan kerapu macan sebesar 1,48\%/hari (Palinggi, 2007).

Penelitian ini bertujuan mengetahui efektivitas beberapa mikroba dalam meningkatkan kualitas bungkil kopra untuk bahan pakan ikan bandeng melalui proses fermentasi.

\section{BAHAN DAN METODE}

\section{Fermentasi Bungkil Kopra}

Perbaikan mutu bungkil kopra dilakukan melalui metode fermentasi. Bungkil kopra yang digunakan dalam fermentasi berasal dari pabrik pengolahan minyak di Sulawesi Selatan. Fermentasi bungkil kopra ini dilakukan dengan menggunakan beberapa jenis mikroba sebagai perlakuan yaitu: (A) Aspergillus niger, (B) Saccharomyces cereviceae, (C) Rhizopus sp., dan (D) Bacillus subtilis. Metode fermentasi dilakukan berdasarkan metode yang dikembangkan 
oleh Palinggi (2008) dengan tahapan proses seperti pada Gambar 1.

\section{Analisis Proksimat}

Bungkil kopra hasil fermentasi yang sudah jadi tepung lalu dianalisis proksimat untuk melihat kelayakannya sebagai bahan pakan ikan bandeng. Analisis proksimat dilakukan berdasarkan metode AOAC International (1999), yaitu protein kasar ditentukan dengan metode Kjeldahl, lemak kasar dengan metode ekstraksi dengan ether menggunakan soxhlet, serat kasar ditentukan dengan reaksi sampel dengan asam dan basa untuk memisahkan serat kasar dari bahan lain, dan kadar abu ditentukan dengan pembakaran dalam tanur pada suhu $550^{\circ} \mathrm{C}$.

\section{Analisis Asam Amino}

Tepung bungkil kopra dianalisis kandungan asam aminonya dengan menggunakan High

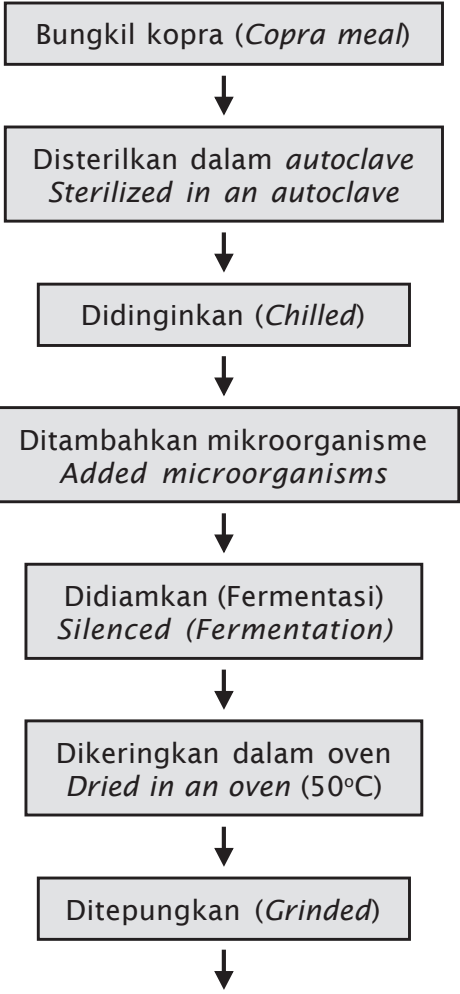

Analisis proksimat (Proximate analysis)

Gambar 1. Skema fermentasi bungkil kopra

Figure 1. Schema for copra cake fermentation
Performance Liquid Chromatography (HPLC) merk Shimadzu type 20 di Laboratorium Terpadu IPB, Bogor. HPLC menggunakan kolom ultra techssspppere, laju aliran fase mobil 1 $\mathrm{mL} /$ menit dan detektor fluoresens. Fase mobil terdiri atas buffer sodium acetat pH 6,5 dan metanol 95\%.

\section{Penentuan Nilai Peroksida}

Tepung bungkil kopra dianalisis ketengikannya dengan mengetahui angka peroksidanya menggunakan metode titrasi di Laboratorium Nutrisi dan Makanan Ternak, Fakultas Peternakan, UNHAS.

\section{Kecernaan}

Analisis kecernaan bahan dilakukan menggunakan pakan dengan komposisi pakan uji seperti pada Tabel 1. Wadah percobaan yang digunakan berupa enam buah bak kerucut bervolume $200 \mathrm{~L}$ yang dilengkapi dengan sistem aerasi dan pergantian air. Ikan bandeng ukuran 50,0 $\pm 2,9 \mathrm{~g}$ ditebar dengan kepadatan 15 ekor/bak. Pakan uji dan pakan kontrol ditambahkan krom oksida $\left(\mathrm{Cr}_{2} \mathrm{O}_{3}\right)$ sebagai indikator masing-masing sebanyak 1\% (Furuichi, 1988). Sebelum pengambilan feses, ikan diadaptasikan dengan pakan uji tersebut selama satu minggu. Ikan diberi pakan uji secara satiasi per hari dengan frekuensi dua kali sehari pada pagi dan sore hari. Beberapa saat setelah pemberian pakan, air dikeluarkan untuk membuang sisa pakan yang ada dengan membuka kran bagian bawah. Pengumpulan feses dilakukan setiap tiga jam, untuk mencegah terjadi leaching nutrien pada feses. Feses yang terkumpul secepatnya disimpan dalam freezer. Feses dikumpulkan sampai mendapatkan jumlah yang cukup untuk analisis, kemudian dikeringkan dengan freeze-dried. Kadar krom dalam sampel pakan dan feses dianalisis berdasarkan prosedur Takeuchi (1988).

Koefisien kecernaan bahan kering, protein, dan lemak dari pakan referensi dan pakan uji dihitung dengan rumus (Takeuchi, 1988):

$$
\operatorname{ADC}(\%)=\left[1-\left[\frac{\mathrm{Md} \times \mathrm{Af}}{\mathrm{Mf} \times \mathrm{Ad}}\right]\right] \times 100
$$

di mana:

$\mathrm{ADC}=$ Apparent digestibility coeficient dari: bahan kering, protein kasar, lemak, dan BETN; Md dan Mf berturut-turut adalah kadar kromium dalam pakan dan feses, Ad dan Af berturut-turut adalah kadar nutrien dalam pakan dan dalam feses 
Tabel 1. Komposisi pakan untuk uji kecernaan bungkil kopra (\%)

Table 1. Feed composition for digestibility trials of copra meal (\%)

\begin{tabular}{lcc}
\hline $\begin{array}{c}\text { Bahan pakan } \\
\text { Feed ingredients }\end{array}$ & $\begin{array}{c}\text { Pakan referensi } \\
\text { Reference diet }\end{array}$ & $\begin{array}{c}\text { Bungkil kopra (Copra cake) } \\
\text { (A, B, C, D, E) }\end{array}$ \\
\hline Tepung ikan (Fish meal) & 15 & 10.5 \\
Bungkil kedelai (Soybean meal) & 25 & 17.5 \\
Dedak halus (Rice bran) & 35 & 24.5 \\
Tepung terigu (Wheat flour) & 14 & 9.8 \\
Limbah pollard (Pollard waste) & 10 & 7 \\
Bungkil kopra (Copra cake) & 0 & 30 \\
Vitamin mix & 0.5 & 0.35 \\
Mineral mix & 0.5 & 0.35 \\
Kromoksida (Chromeoxide) & 1 & 1 \\
\hline
\end{tabular}

Keterangan (Note):

A = Bungkil kopra tanpa fermentasi (Copra meal without fermentation)

$\mathrm{B}=$ Bungkil kopra yang difermentasi dengan A.niger (Copra cake fermented with A. niger)

$\mathrm{C}$ = Bungkil kopra yang difermentasi dengan S. cereviceae (Copra cake fermented with S. cereviceae)

$\mathrm{D}=$ Bungkil kopra yang difermentasi dengan Rhizophus (Copra cake fermented with Rhizophus)

$\mathrm{E}=$ Bungkil kopra yang difermentasi dengan B. subtilis (Copra cake fermented with B. subtilis)

Koefisien kecernaan (ADC) dari bahan pakan (bungkil kopra) dihitung berdasarkan formula yang dikembangkan oleh Pfeffer et al. (1995) dengan rumus sebagai berikut:

$$
\mathrm{ADC}_{\mathrm{NI}}=\frac{1}{\alpha}\left\{\mathrm{AD}_{\mathrm{NT}}-(1-\alpha) \mathrm{AD}_{\mathrm{NR}}\right\}
$$

di mana:

$A D C_{N 1}, A D_{N T}$, dan $A D_{N R}$ adalah koefisien kecernaan nutrien berturut-turut dari bahan pakan (bungkil kopra), pakan uji, dan pakan referensi. $\alpha$ adalah nilai substitusi yang dihitung berdasarkan proporsi nutrien yang dikontribusikan oleh bahan test (bungkil kopra) dalam pakan referensi (Bureau et al., 1999)

Komposisi proksimat dan kecernaan nutrien bungkil kopra hasil fermentasi dianalisis ragam berdasarkan rancangan acak kelompok (masing-masing dua kelompok berdasarkan waktu (20 hari)), jika terdapat perbedaan yang nyata di antara perlakuan, maka dilanjutkan dengan uji Tukey (Steel \& Torrie, 1995). Sementara kandungan asam amino dan angka peroksida dianalisis secara deskriptif.

\section{HASIL DAN BAHASAN}

Metode fermentasi merupakan salah satu upaya untuk meningkatkan kualitas bahan baku untuk pemanfaatannya sebagai pakan ikan. Hasil fermentasi bungkil kopra dengan menggunakan beberapa jenis mikroba yaitu A. niger, S. cereviceae, Rhizopus sp., dan $B$. subtilis disajikan pada Tabel 2.

Pada Tabel 2 terlihat bahwa hasil uji statistik terhadap kandungan protein tertinggi diperoleh pada bungkil kopra yang difermentasi dengan Rhizophus sp. dan berbeda $(\mathrm{P}<0,05)$ dengan bungkil kopra tanpa fermentasi tetapi tidak berbeda $(P>0,05)$ dengan bungkil kopra yang difermentasi dengan $A$. niger, $S$. cereviceae, dan $B$. subtilis. Terjadinya peningkatan protein disebabkan adanya kenaikan jumlah massa sel mikroba selama fermentasi berlangsung (Wang et al., 1979; Halid, 1991).

Salah satu variabel penting dalam menilai kualitas bahan baku pakan khususnya jika berperan sebagai sumber protein adalah kandungan asam aminonya. Asam amino merupakan komponen penyusun utama protein, sehingga untuk menentukan kualitas protein bahan pakan maka perlu diperhatikan komposisi asam amino, bahan pakan, dan ketersediaan biologisnya. Pada Tabel 3 disajikan komposisi asam amino bungkil kopra hasil fermentasi. Pada Tabel 3 terlihat bahwa bungkil kopra yang difermentasi dengan Rhizopus sp. memiliki total asam amino esensial tertinggi dibandingkan dengan bungkil kopra 
Tabel 2. Hasil analisis proksimat bungkil kopra (\% bobot kering)*

Table 2. Proximate composition of copra cake (\% dry weight)

\begin{tabular}{lcccc}
\hline \multirow{1}{*}{$\begin{array}{c}\text { Bungkil kopra } \\
\text { Copra cake }\end{array}$} & $\begin{array}{c}\text { Protein kasar } \\
\text { Crude protein }\end{array}$ & $\begin{array}{c}\text { Lemak kasar } \\
\text { Crude Fat }\end{array}$ & $\begin{array}{c}\text { Serat kasar } \\
\text { Crude Fiber }\end{array}$ & $\begin{array}{c}\text { Abu } \\
\text { Ash }\end{array}$ \\
\cline { 2 - 5 } & $20.61 \pm 0.43^{\mathrm{b}}$ & $10.44 \pm 0.66^{\mathrm{ab}}$ & $22.66 \pm 3.23^{\mathrm{a}}$ & $7.13 \pm 0.67^{\mathrm{a}}$ \\
\hline $\begin{array}{l}\text { Tanpa fermentasi } \\
\text { Without fermentation }\end{array}$ & & & \\
\hline Dengan ferment asi (Fermentation wit $\boldsymbol{h}$ ): $^{\text {A. niger }}$ & $26.09 \pm 2.16^{\mathrm{ab}}$ & $12.56 \pm 4.65^{\mathrm{ab}}$ & $25.70 \pm 1.27^{\mathrm{a}}$ & $10.12 \pm 0.20^{\mathrm{a}}$ \\
S. cereviceae & $25.95 \pm 1.83^{\mathrm{ab}}$ & $11.42 \pm 3.44^{\mathrm{ab}}$ & $25.08 \pm 4.16^{\mathrm{a}}$ & $8.78 \pm 0.69^{\mathrm{a}}$ \\
Rhizophus $s p$. & $29.30 \pm 0.04^{\mathrm{a}}$ & $5.22 \pm 0.01^{\mathrm{b}}$ & $16.52 \pm 0.36^{\mathrm{a}}$ & $7.21 \pm 0.16^{\mathrm{a}}$ \\
B. subtilis & $24.94 \pm 0.26^{\mathrm{ab}}$ & $20.38 \pm 1.92^{\mathrm{a}}$ & $22.02 \pm 3.85^{\mathrm{a}}$ & $5.49 \pm 1.15^{\mathrm{a}}$ \\
\hline
\end{tabular}

Nilai pada kolom yang sama diikuti huruf superscript yang berbeda menunjukkan berbeda nyata $(\mathrm{P}<0,05)$ (Value within the same column with the different superscript letters are significantly different $(P<0.05))$

Tabel 3. Komposisi asam amino tepung bungkil kopra (\% B/B)

Table 3. Amino acid composition of copra cake flour (\% W/W)

\begin{tabular}{lccccc}
\hline $\begin{array}{l}\text { Jenis asam amino } \\
\text { Type of amino acid }\end{array}$ & BKTF & \multicolumn{3}{c}{ Bungkil kopra ferment asi (Fermented copra cake) } \\
\cline { 3 - 6 } & & A. niger & S. cereviceae & Rhizopus sp. & B. subtilis \\
\hline Non-AAE & & & & & \\
Aspartic acid & 1.73 & 1.96 & 1.67 & 2.38 & 1.79 \\
Glutamic acid & 4.15 & 4.66 & 4.67 & 4.88 & 4.45 \\
Glycine & 0.79 & 0.61 & 0.56 & 1.02 & 0.57 \\
Alanine & 0.92 & 1.11 & 1.15 & 1.29 & 1.05 \\
Tyrosine & 0.52 & 0.63 & 0.78 & 0.75 & 0.56 \\
Serine & 0.95 & 1.09 & 0.74 & 1.12 & 0.99 \\
\hline Jumlah (Total) non-AAE & 9.06 & 10.06 & 9.58 & 11.44 & 9.41 \\
\hline AAE: & & & & & \\
Histidine & 0.53 & 0.50 & 0.46 & 0.56 & 0.50 \\
Threonime & 0.72 & 0.83 & 0.73 & 0.87 & 0.74 \\
Arginine & 2.36 & 2.67 & 1.82 & 2.30 & 2.56 \\
Methionine & 0.33 & 0.41 & 0.41 & 0.45 & 0.39 \\
Valine & 1.06 & 1.23 & 1.16 & 1.36 & 1.15 \\
Phenylalanine & 0.93 & 1.05 & 1.16 & 1.29 & 0.99 \\
I-leucine & 0.72 & 0.85 & 0.78 & 1.02 & 0.77 \\
Leucine & 1.35 & 1.48 & 1.36 & 1.70 & 1.40 \\
Lysine & 0.52 & 0.77 & 1.06 & 0.95 & 0.67 \\
\hline Jumlah (Total) AAE & 8.52 & 7.79 & 8.94 & 10.05 & 9.17 \\
\hline
\end{tabular}

BKTF = Bungkil kopra tanpa fermentasi (Copra cake without fermentation); AAE = Asam amino esensial (Essential amino acid) 
yang difermentasi mikroba lainnya maupun bungkil kopra yang tidak difermentasi.

Pada ikan, protein pakan selain digunakan sebagai komponen penyusun protein tubuh (pertumbuhan), juga digunakan sebagai salah satu sumber utama kebutuhan energi. Oleh karena itu, ikan membutuhkan protein pakan yang cukup tinggi dalam pakannya. Peningkatan kandungan protein bungkil kopra melalui fermentasi dengan Rhizopus sp. berpeluang meningkatkan pemanfaatan bungkil kopra sebagai sumber protein dalam pakan ikan khususnya ikan-ikan herbivora dan omnivora.

Selain kandungan asam amino esensial, nilai kecernaan bahan juga merupakan indikator penting dalam menilai mutu bahan baku pakan. Nilai koefisien kecernaan bungkil kopra setelah difermentasi dengan beberapa mikroba disajikan pada Tabel 4. Hasil analisis ragam menunjukkan bahwa nilai koefisien kecernaan protein bungkil kopra berbeda nyata $(\mathrm{P}<0,05)$ di antara perlakuan. Nilai koefisien kecernaan protein tertinggi diperoleh pada bungkil kopra yang difermentasi dengan $A$. niger dan Rhizopus sp., disusul berturut-turut S. cereviceae, B. subtilis, dan terendah pada bungkil kopra yang tidak difermentasi. Hal ini menjelaskan bahwa perlakuan fermentasi dapat meningkatkan kecernaan protein bungkil kopra. Amalia et al. (2013) mengemukakan bahwa tingginya tingkat kecernaan pakan dapat meningkatkan tingkat penyerapan asam amino ke dalam tubuh untuk pertumbuhan.
Dari hasil uji statistik terhadap kandungan lemak diperoleh bahwa bungkil kopra yang difermentasi dengan $B$. subtilis mempunyai kandungan lemak tertinggi dan berbeda nyata $(P<0,05)$ dengan bungkil kopra yang difermentasi dengan Rhizopus sp. tetapi tidak berbeda nyata $(P>0,05)$ dengan bungkil kopra yang difermentasi dengan A. niger dan S. cereviceae (Tabel 2). Terjadinya peningkatan kandungan lemak dalam pakan yang difermentasi dengan A. niger, S. cereviceae, dan B. subtilis mungkin disebabkan adanya penambahan lemak dari kapang yang digunakan. Ganjar (1983) mengemukakan bahwa terjadinya peningkatan lemak kasar pada media fermentasi disebabkan adanya kandungan lemak kasar yang berasal dari massa sel mikroba yang tumbuh dan berkembang biak pada media selama fermentasi. Hal yang sama juga terjadi pada dedak halus yang difermentasi dengan A. niger (Rahma, 1996 dan Palinggi, 2009). Haryati et al. (1997) melaporkan bahwa fermentasi dengan menggunakan kapang $A$. niger NRRL (North Carolina Research Laboratory, USA) 337 dapat menurunkan kadar lemak pada substrat bungkil kelapa. Penurunan kadar lemak yang terjadi mungkin disebabkan oleh perbedaan tipe kapang yang digunakan. Pada penelitian ini digunakan $A$. niger produksi PAU, IPB, sedangkan kapang yang digunakan Haryati et al. (1997) adalah A. niger NRRL 337. Menurut Supriyati et al. (1998), penggunaan A. niger NRRL 337 lebih baik daripada A. niger tipe liar (produksi Balai Penelitian Ternak, Ciawi). Hal

Tabel 4. Nilai koefisien kecernaan bungkil kopra*

Table 4. Digestibility coefficient value of copra cake

\begin{tabular}{lccc}
\hline \multirow{1}{*}{$\begin{array}{c}\text { Bungkil kopra } \\
\text { Copra cake }\end{array}$} & \multicolumn{3}{c}{$\begin{array}{c}\text { Koefisien kecernaan } \\
\text { Digestibility coefficients (\%) }\end{array}$} \\
\cline { 2 - 4 } & $\begin{array}{c}\text { Bahan kering } \\
\text { Dry matter }\end{array}$ & $\begin{array}{c}\text { Protein } \\
\text { Protein }\end{array}$ & $\begin{array}{c}\text { Lemak } \\
\text { Fat }\end{array}$ \\
\hline Tanpa fermentasi & $52.7 \pm 1.25^{\mathrm{a}}$ & $75.1 \pm 2.52^{\mathrm{a}}$ & $84.5 \pm 0.76^{\mathrm{a}}$ \\
Without fermentation & & & \\
\hline Dengan fermentasi (Fermentation with $):$ & & \\
A. niger & $51.3 \pm 12.42^{\mathrm{a}}$ & $90.7 \pm 4.36^{\mathrm{c}}$ & $97.0 \pm 0.10^{\mathrm{b}}$ \\
S. cereviceae & $48.8 \pm 7.14^{\mathrm{a}}$ & $85.7 \pm 4.09^{\mathrm{b}}$ & $93.4 \pm 0.65^{\mathrm{b}}$ \\
Rhizophus sp. & $54.3 \pm 8.32^{\mathrm{a}}$ & $88.1 \pm 4.64^{\mathrm{bc}}$ & $97.2 \pm 0.38^{\mathrm{b}}$ \\
B. subtilis & $52.5 \pm 2.76^{\mathrm{a}}$ & $79.3 \pm 1.06^{\mathrm{ab}}$ & $84.1 \pm 3.12^{\mathrm{a}}$ \\
\hline
\end{tabular}

Nilai pada kolom yang sama diikuti huruf superscript yang berbeda menunjukkan berbeda nyata $(\mathrm{P}<0,05)$ (Value within the same column with the different superscript letters are significantly different $(P<0.05))$ 
ini disebabkan tipe NRRL 337 lebih spesifik aktivitasnya untuk medium yang mempunyai kandungan lemak cukup tinggi. Hal ini diamati juga oleh Purwadaria et al. (1997) bahwa penggunaan kapang tipe NRRL 337 pada fermentasi bungkil kelapa yang kandungan lemaknya tinggi, lebih baik daripada menggunakan kapang tipe liar.

Pada bungkil kopra yang difermentasi dengan Rhizopus sp. terjadi penurunan kandungan lemak. Hal ini disebabkan karena adanya lemak yang dikonsumsi oleh kapang untuk menunjang pertumbuhannya pada substrat. Terjadinya penurunan lemak pada bungkil kopra menunjukkan bahwa Rhizopus sp. menghasilkan enzim lipase. Hal ini dijelaskan oleh Darwis \& Sukara (1990) bahwa salah satu jenis kapang penghasil enzim lipase adalah Rhizopus. Selanjutnya Balcao et al. (1996) mengatakan bahwa beberapa reaksi katalisis terjadi oleh enzim lipase antara lain hidrolisis, sintesis ester, dan alkoholosis. Dengan adanya aktivitas enzim lipase ini, maka produk fermentasi yang dihasilkan menyebabkan kadar lemaknya berkurang.

Koefisien kecernaan lemak tertinggi terjadi pada bungkil kopra yang difermentasi dengan Rhizopus sp., A. niger, dan S. cereviceae, koefisien kecernaan yang diperoleh ini tidak berbeda nyata $(P>0,05)$ di antara ketiganya. Koefisien kecernaan terendah diperoleh pada fermentasi dengan $B$. subtilis dan tanpa fermentasi. Dari nilai koefisien kecernaan lemak ini memperlihatkan bahwa kadar lemak yang tinggi dalam bungkil kopra akibat fermentasi tidak memengaruhi koefisien kecernaan lemak tersebut bagi ikan bandeng bahkan dapat meningkatkan koefisien kecernaan lemaknya. $\mathrm{Hal}$ ini dapat terjadi karena adanya enzim lipase yang terdapat dalam pakan yang dapat mendegradasi lemak. Adanya enzim dalam saluran pencernaan sangat memengaruhi daya cerna ikan terhadap pakan (NRC, 1983).

Kandungan serat kasar bungkil kopra yang telah difermentasi tidak berbeda nyata $(P>$ $0,05)$ pada semua perlakuan namun demikian cenderung terjadi peningkatan kandungan serat kasar pada fermentasi dengan $A$. niger dan S. cereviceae. Sedang fermentasi dengan menggunakan Rhizopus sp. dan B. subtilis cenderung mengalami penurunan (Tabel 2). Meningkatnya kandungan serat kasar bahan yang difermentasi disebabkan terbentuknya dinding sel miselia kapang yang mengandung selulosa (serat kasar) (Shurtleff \& Aoyagy,
1979). Sedang menurunnya serat kasar pada fermentasi bahan disebabkan tercernanya serat kasar oleh mikroba. Menurut Satiawiharja (1984), menurunnya serat kasar dalam bahan fermentasi dapat disebabkan oleh tercernanya bagian dari serat kasar oleh mikroba yang biasanya sulit dicerna oleh ternak monogastrik. Hal ini didukung oleh pendapat Winarno \& Fardiaz (1979) yang menyatakan proses fermentasi menyebabkan terjadinya pemecahan oleh enzim-enzim tertentu terhadap bahanbahan yang tidak dapat dicerna, misalnya selulosa dan hemiselulosa menjadi gula sederhana. Judoamidjojo et al. (1989) mengemukakan senyawa karbohidrat kompleks seperti pati, selulosa, pektin, lignoselulosa, dan serat umumnya dapat digunakan sebagai sumber $C$ dan sumber energi medium fermentasi, secara biologis senyawa karbohidrat kompleks dapat diubah menjadi glukosa, maltosa, etanol, dektrin, dan asam-asam organik yang bernilai ekonomis tinggi.

Dari hasil uji statistik terhadap kadar abu memperlihatkan tidak ada perbedaan yang nyata $(P>0,05)$ di antara perlakuan yang diuji (Tabel 2). Namun demikian cenderung terjadi peningkatan kadar abu pada bungkil kopra yang difermentasi dengan $A$. niger, $S$. cereviceae, dan Rhizopus sp. dan penurunan pada fermentasi dengan $B$. subtilis. Pengukuran kadar abu bertujuan untuk mengetahui besarnya kandungan mineral yang terdapat dalam bahan pakan. Fardiaz (1988) menyatakan bahwa peningkatan kadar abu selama fermentasi disebabkan oleh bertambahnya massa sel tubuh kapang dan terjadinya peningkatan konsentrasi di dalam produk karena perubahan-perubahan bahan organik akibat proses biokonversi yang menghasilkan $\mathrm{H}_{2} \mathrm{O}$ dan $\mathrm{CO}_{2}$.

Koefisien kecernaan bahan kering bungkil kopra tidak memberikan perbedaan yang nyata $(P>0,05)$ pada semua perlakuan (Tabel 4). Kecernaan bahan kering diukur untuk mengetahui jumlah zat makanan yang diserap tubuh yang dilakukan melalui analisis dari jumlah bahan kering, baik dalam pakan maupun dalam feses. Selisih jumlah bahan kering yang dikonsumsi dan jumlah yang diekskresikan adalah kecernaan bahan kering (Ranjhan, 1980). Kecernaan bahan kering menunjukkan kecernaan dari seluruh zat-zat makanan yang dapat dicerna oleh tubuh. Hasil penelitian menunjukkan bahwa penggunaan bungkil kopra produk fermentasi dalam pakan memberikan 


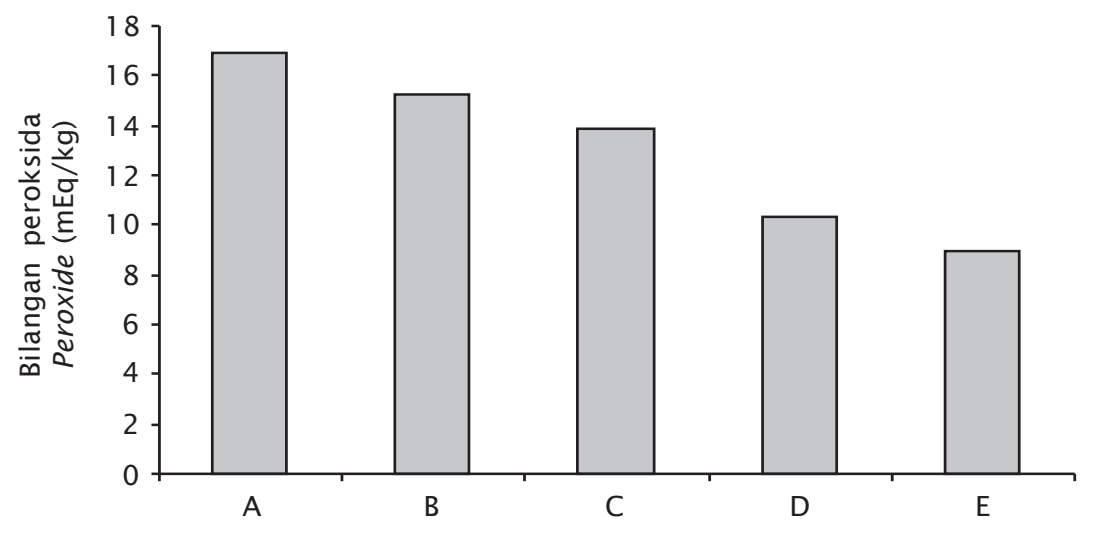

Jenis mikroba (Species of microbes)

Keterangan (Note):

$\mathrm{A}=$ Tanpa fermentasi (Without fermentation)

$\mathrm{B}=$ Fermentasi dengan A.niger (Fermentation with A. niger)

$\mathrm{C}=$ Fermentasi dengan $S$. cereviceae (Fermentation with S. cereviceae)

$\mathrm{D}=$ Fermentasi dengan Rhizophus (Fermentation with Rhizophus)

$\mathrm{E}=$ Fermentasi dengan B. subtilis (Fermentation with B. subtilis)

Gambar 2. Nilai bilangan peroksida bungkil kopra yang difermentasi dengan mikroba berbeda

Figure 2. Peroxide value of copra cake fermented with different microbes

pengaruh yang sama baiknya terhadap nilai kecernaan bahan kering pakan tanpa fermentasi. Artinya kandungan zat-zat gizi yang terdapat dalam bungkil kopra yang difermentasi memenuhi standar zat-zat gizi. Kecernaan bahan kering pakan yang tidak memperlihatkan perbedaan ini, dimungkinkan karena bungkil kopra yang telah diproses secara biologis melalui fermentasi mampu meningkatkan kandungan zat-zat makanan dan daya cerna makanan. Nilai kecernaan bahan kering yang tinggi menunjukkan tingginya kualitas pakan.

Salah satu permasalahan dalam pemanfaatan bungkil kopra sebagai bahan pakan ikan adalah seringnya berbau tengik. Potensi suatu bahan menjadi tengik ditentukan dengan bilangan peroksida di mana terjadi reaksi iodisasi pada ikatan rangkap asam lemak (Berger \& Hamilton, 1992). Bau tengik pada bungkil kopra tersebut timbul akibat adanya pemecahan atau kerusakan minyak yang membentuk peroksida. Ukuran dari ketengikan ini dapat diketahui dengan menentukan bilangan peroksidanya. Semakin tinggi nilai bilangan peroksidanya, maka semakin tinggi pula nilai ketengikan atau kerusakan minyak tersebut. Tingginya angka peroksida juga sebagai aki- bat dari proses oksidasi pada saat pemasakan atau penyimpanan (Aisyah et al., 2010). Hasil analisis bilangan peroksida bungkil kopra hasil fermentasi dapat dilihat pada Gambar 2.

Dari Gambar 2 terlihat terjadi penurunan bilangan peroksida pada bungkil kopra setelah dilakukan fermentasi. Hal ini sesuai dengan yang diperoleh Hamid et al. (1999) bahwa proses fermentasi dapat menghambat munculnya ketengikan pada bungkil kelapa.

\section{KESIMPULAN}

Fermentasi dapat meningkatkan kualitas bungkil kopra dengan meningkatnya kandungan protein, meningkatnya nilai koefisien kecernaan protein, dan lemak untuk ikan bandeng, serta menurunkan bilangan peroksida. Fermentasi bungkil kopra menggunakan Rhizopus sp. memberikan hasil terbaik.

\section{DAFTAR ACUAN}

Abun. (2007). Pengukuran nilai kecernaan ransum yang mengandung limbah udang windu produk fermentasi pada ayam broiler. Makalah ilmiah. Jurusan Nutrisi dan Makanan Ternak. Fakultas Peternakan Universitas Padjadjaran. $34 \mathrm{hlm}$. 
Ahmad, R.Z. (2005). Pemanfaatan khamir Saccharomyces cerevisiae untuk ternak. WARTAZOA, 15(I), 49-55.

Ahmad, R.Z. (2007). Aktivitas enzim kitinase dan protease pada cendawan Nematofagus (Duddingtonia flagrans dan Saccharomyces cereviceae). Seminar Nasional Teknologi Peternakan dan Veteriner. hlm. 885891.

Aisyah, S., Yulianti, E., \& Fasya, A.G. (2010). Penurunan angka peroksida dan asam lemak bebas (FFA) pada proses bleaching minyak goreng bekas oleh karbon aktif polong buah kelor (Moringa oliefera, Lamk) dengan aktivasi $\mathrm{NaCl}$. Alchemy, 1(2), 93-103.

Amalia, R., Subandiyono, \& Arini, E. (2013). Pengaruh penggunaan papain terhadap tingkat pemanfaatan protein pakan dan pertumbuhan lele dumbo (Clarias gariepinus). Journal of Aquaculture Management and Technology, 2(1), 136-143.

AOAC International. (1999). Official methods of analysis. $16^{\text {th }}$ eds. Association of Official Analytical Chemists International, Gaithersberg, Maryland. USA, 1,141 pp.

Balcao, V.M., Paiva, A.L., \& Malcata, F.X. (1996). Review bioreactor with immobilized lipases: State of the art. Enzyme and Microbial Technology, 18, 392-416.

Berger, K.G. \& Hamilton. (1992). Lipids and oxygen - is rancidity avoidable In Member of Three SCl Groups. Mini Review Compilation Biodegradation and Biotransformations of Oils and Fats. J. Chem. Tech. Biotechnol., 55, 397-414.

Bureau, D.P., Harris, A.M., \& Cho, C.Y. (1999). Apparent digestibility of rendered animal protein ingredients for rainbow trout (Oncorhynchus mykiss). Aquaculture, 180, 345-358.

Child, R. (1964). Coconut. Longman. London, $76 \mathrm{pp}$.

Darwis, A.A. \& Sukara, E. (1990). Teknologi microbial. Departemen Pendidikan dan Kebudayaan. Direktorat Jenderal Pendidikan Tinggi. Pusat Antar Universitas Bioteknologi. Institut Pertanian Bogor. Bogor, $337 \mathrm{hlm}$.

Fardiaz, S. (1988). Fisiologi fermentasi. Pusat Antar Universitas Pangan dan Gizi. Institut Pertanian Bogor. Bogor, $186 \mathrm{hlm}$.

Fardiaz, S. (1989). Mikrobiologi pangan. Departemen Pendidikan dan Kebudayaan, Direktorat Jenderal Pendidikan Tinggi, Pusat Antar Universitas Pangan dan Gizi, Institut Pertanian Bogor. Bogor, $268 \mathrm{hlm}$.
Furuichi, M. (1988). Carbohydrate. In Watanabe, $\mathrm{T}$, (Ed.), Fish Nutrition and Mariculture. Department of Aquatic Biosciences, University of Fisheries. Tokyo, p. 44-55.

Ganjar, I. (1983). Pemanfaatan ampas tape ketan. Departemen Kesehatan. Jakarta, $7 \mathrm{hlm}$.

Graumann, P. (2007). Bacillus: Cellular and molecular biology. Caister Academic Press. USA, p. 34-36.

Halid, I. (1991). Perubahan nilai nutrisi onggok yang diperkaya nitrogen bukan protein selama proses fermentasi dengan biakan kapang. Tesis. Fakultas Pasca Sarjana. Institut Pertanian Bogor. Bogor, $113 \mathrm{hlm}$.

Hamid, H., Purwadaria, T., Hayati, T., \& Sinurat, A.P. (1999). Perubahan nilai bilangan peroksida bungkil kelapa dalam proses penyimpanan dan fermentasi dengan Aspergillus niger. Jurnal Ilmu Ternak dan Veteriner, 4(2), 101-106.

Haryati, T., Purwadaria, T., Darma, J., \& Tangendjaja, B. (1997). Production of extracellular glycosidases by Eupenicilium javanicum and Aspergillus niger NRRL 337 on the coconut meal substrate. Second Conference on Agriculture Biotechnology. Jakarta, June 13-15, 1995. Indonesia, p. 517522.

Judoamidjojo, R.M., Said, E.G., \& Hartoto, L. (1989). Biokonversi. Pusat Antar Universitas Bioteknologi., IPB.Ditjen Dikti. Departemen Pendidikan dan Kebudayaan. $99 \mathrm{hlm}$.

Karmini, M., Sutopo, D., \& Hermana. (1996). Aktivitas enzim hidrolitik kapang Rhizopus sp. pada proses fermentasi tempe. J. Penelitian Gizi dan Makanan, 19, 93-102.

Lampen, O.J. (1968). External enzymes of yeast. In Ahmad, R.Z. (Ed.), Aktivitas enzim kitinase dan protease pada cendawan $\mathrm{Ne}$ matofagus (Duddingtonia flagrans dan Saccharomyces cereviceae). Seminar Nasional Teknologi Peternakan dan Veteriner. hlm. 885-891.

Lodder, J. (1970). The yeast. A Taxonomic Study. In Ahmad, R.Z. (Ed.), Aktivitas enzim kitinase dan protease pada cendawan Nematofagus (Duddingtonia flagrans dan Saccharomyces cereviceae). Seminar Nasional Teknologi Peternakan dan Veteriner. hlm. 885-891.

Madigan, M.T. \& Martinko, J.M. (2006). Brock Biology of Microorganisms $11^{\text {th }}$ ed. New Jersey: Pearson Education. p. 178-185.

Nutritional Research Council (NRC). (1983). Nutrition requirement of warm water fishes 
and shellfish. National Academic of Sciences. Washington D.C., 102 pp.

Palinggi, N.N. (2003). Pengaruh penambahan Aspergillus niger dalam dedak halus terhadap kecernaan pakan ikan kerapu bebek, Cromileptes altivelis. Prosiding SemiLoka Aplikasi Teknologi Pakan dan Peranannya Bagi Perkembangan Usaha Perikanan Budidaya. Pusat Riset Perikanan Budidaya. Badan Riset Kelautan dan Perikanan. Departemen Kelautan dan Perikanan. hlm. 179-182.

Palinggi, N.N. (2007). Mikro organisme pada bungkil kopra untuk bahan pakan ikan kerapu macan, Epinephelus fuscoguttatus. Laporan Hasil Riset. Balai Riset Perikanan Budidaya Air Payau. Maros, $7 \mathrm{hlm}$.

Palinggi, N.N. (2008a). Pengaruh penambahan Aspergillus niger dalam tepung darah terhadap kecernaan pakan ikan kerapu bebek, Cromileptes altivelis. Prosiding Seminar Nasional Perikanan dan Kelautan. $4 \mathrm{hlm}$.

Palinggi, N.N. (2008b). Studi pendahuluan perubahan kandungan protein dan lemak dalam bungkil kopra yang difermentasi dengan fungi. Prosiding Seminar Nasional Perikanan dan Kelautan. Universitas Brawijaya, Malang, $6 \mathrm{hlm}$.

Palinggi, N.N. (2009). Penambahan Aspergillus niger dalam dedak halus sebagai bahan pakan pada pembesaran ikan kerapu bebek. Prosiding Seminar Nasional Perikanan 2009. Pusat Penelitian dan Pengabdian Masyarakat. Sekolah Tinggi Perikanan. Jakarta, $7 \mathrm{hlm}$.

Pfeffer, E., Kinzinger, S., \& Rodehutscord, M. (1995). Influence of the proportion of poultry slaughter by-products and of untreated or hydrothermically treated legume seeds in diets for rainbow trout, Oncorhynchus mykiss (Walbaum), on apparent digestibilities of their energy and organic compounds, Aquacult. Nutr., 1, 111 117.

Purwadaria, T., Haryati, T., Sinurat, A.P., Darma, J., \& Pasaribu, T. (1997). In vitro nutrient value of coconut meal fermented with Aspergillus niger NRRL 337 at different enzymatic incubation temperatures. Proceed- ings Second Conference on Agriculture Biotechnology. Jakarta, 13-15 June 1995. Indonesia, p. 532-542.

Rahma, S.N. (1996). Evaluasi kandungan zat makanan dedak halus yang difermentasi dengan Aspergillus niger, Aspergillus oryzae, dan Rhizopus oryzae. Skripsi. Fakultas Peternakan, Institut Pertanian Bogor. Bogor, $51 \mathrm{hlm}$.

Ranjhan, S.K. (1980). Animal nutrition in tropics. Vikas Publishing house Pvt. Ltd. Sahibabad, Ghaziabad. New Delhi, 462 pp.

Satiawiharja, B. (1984). Fermentasi media padat dan manfaatnya. Ditjen Dikti, Departemen Pendidikan dan Kebudayaan. Jakarta, $109 \mathrm{hlm}$.

Shurtleff, W. \& Aoyagy, A. (1979). The book of Tempeh: A super soyfood from Indonesia. Harper and Row. New York, 257 pp.

Steel, R.G.D. \& Torrie, J.H. (1995). Prinsip dan prosedur statistika. Alih bahasa: Sumantri, B. Gramedia Pustaka Utama. Jakarta, 748 hlm.

Suhartono, M.T. (1989). Enzim dan bioteknologi. Departemen Pendidikan dan Kebudayaan, Direktorat Jenderal Pendidikan Tinggi Antar Universitas Bioteknologi, Institut Pertanian Bogor. Bogor, $322 \mathrm{hlm}$.

Supriyati, Pasaribu, T., Hamid, H., \& Sinurat, A. (1998). Fermentasi bungkil inti sawit secara substrat padat dengan menggunakan Aspergillus niger. J. Ilmu Ternak dan Veteriner, 3(3), 165-170.

Takeuchi, T. (1988). Laboratory work-chemical evaluation of dietary nutrients. In Watanabe, T. (Ed.), Fish Nutrition and Mariculture. JICA Kanagawa International Fisheries Training Centre. Tokyo, p. 179-233.

Wang, D.I.C., Coney, C.L., Damain, A.L., Dunnil, P., Humherey, A.F., \& Lily, M.D. (1979). Fermentation and enzymes Technology. John Wiley and Sons. New York, 86 pp.

Winarno, F.G. \& Fardiaz, S. (1979). Biofermentasi dan biosintesa protein. Angkasa. Bandung, $98 \mathrm{hlm}$.

Woodrof, J.G. (1979). Coconut: Production, processing and product. $2^{\text {nd }}$ Edition. The AVI Publ. Co. Inc., Wesport. Connecticut, 165 pp. 